\title{
Identification and control of wood-deteriorating fungi*
}

\section{Identificação e controle de fungos deterioradores de madeira}

\author{
Lilian Gonçalves Mariano 1** (1) (orcid.org/0000-0002-1176-452X) \\ Acácio Geraldo de Carvalho' (1) (orcid.org/0000-0002-0935-7773) \\ Henrique Trevisan' ${ }^{1}$ (i) (orcid.org/0000-0003-0155-231X) \\ Maria do Carmo Araújo Fernandes ${ }^{2}$ (1) (orcid.org/0000-0002-9193-4268)
}

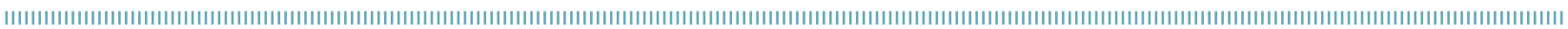

\begin{abstract}
Wood is rich in organic compounds; thus, it is susceptible to attacks by several deteriorating agents because they acknowledge such attacks as a necessary energy supply. Fungi stand out among these agents since they can attack the wood in trees (before felling) and in several post-felling stages. Fungi are biological agents that use organic compounds as food sources, and that is the reason why they degrade most chemical components found in wood. Wood attacked by fungi suffers significant value loss, since these degrading agents affect their mechanical and aesthetic properties. Fungi — which are classified as staining, molding and rotting — are one of the main responsible for the biggest losses in the timber industry. Wood can be virtually used in a whole range of environments, a fact that makes it susceptible to attacks by different fungal species, since the ideal conditions for fungal development change from species to species. In other words, the fact that one or more fungal species are capable of deteriorating wood is directly related to conditions wood is subjected to. Thus, it is essential knowing how to evaluate fungal attacks, symptoms to be taken into consideration at the time to identify the type of attacking organism and the attack stage, as well as the control and prevention measures to be applied to these organisms.
\end{abstract}

KEYWORDS: biodegradation; forest phytopathology; xylophagous organisms; wood preservation.
RESUMO: Rica em compostos orgânicos, a madeira é suscetível ao ataque de diversos agentes deterioradores por ser reconhecida como suprimento necessário de energia. Entre esses agentes, destacam-se os fungos, cujo início de ataque pode se dar ainda na árvore, antes do abate e nas diversas fases posteriores. Os fungos são agentes biológicos que necessitam de compostos orgânicos como fontes de alimento e, por essa razão, degradam grande parte dos componentes químicos da madeira. As madeiras, quando atacadas por fungos, sofrem grandes perdas de valor, afetando suas propriedades mecânicas e estéticas. Os fungos são considerados um dos principais responsáveis pelos maiores prejuízos na indústria madeireira e são classificados como manchadores, emboloradores e apodrecedores. Praticamente, a madeira pode estar em uso em uma variedade de ambientes; sabendo-se que as condiçóes ideais de desenvolvimento de um fungo são diferentes para cada espécie, a madeira ficará suscetível ao ataque por diferentes espécies de fungos. Ou seja, o fato de uma ou mais espécies de fungos serem encontradas deteriorando a madeira está diretamente relacionado às condiçóes em que ela se encontra. Dessa forma, torna-se importante saber como avaliar os ataques feitos por fungos, os sintomas a serem considerados para identificar o tipo de organismo e o estágio do ataque, bem como as medidas de controle e prevenção desses organismos.

PALAVRAS-CHAVE: biodegradação; fitopatologia florestal; organismos xilófagos; preservação da madeira.

\footnotetext{
'Universidade Federal Rural do Rio de Janeiro - Seropédica (RJ), Brazil

${ }^{2}$ Empresa de Pesquisa Agropecuária do Estado do Rio de Janeiro - Seropédica (RJ), Brazil

*This paper is part of the dissertation thesis of the first author.

**Corresponding author: lilian_mariano@hotmail.com

Received on: 02/28/2020. Accepted on: 06/21/2020
} 
Fungi are biological agents that use organic compounds as food sources, and that is the reason why they degrade most polymeric compounds found in wood. They are a group of organisms that lead to significant economic losses in the timber industry, as well as that hinder different wood and wood-derived product uses by negatively affecting their mechanical and aesthetic properties.

Wood is acknowledged by several fungal species as a necessary energy supply because it is rich in organic compounds (POPESCU et al., 2010). These organisms feed on plant cell wall constituents - i.e., on cellulose, hemicellulose and lignin —; consequently, they lead to decreased wood density, mechanical and physical resistance, and life span (ALMEIDA, 2010).

According to SANTOS (1992), wood attacked by fungi undergoes changes in its chemical composition; in addition, it shows decreased mass and mechanical resistance, variation in its natural color, increased permeability, among other effects. As stated by KELLEY et al. (2002), wood devaluation resulting from discoloration and deterioration caused by fungi leads to significant losses in the timber industry.

Besides organic material, fungal development depends on other factors such as moisture content, oxygen, temperature and pH (TEIXEIRA et al., 1997; MORESCHI, 2013). MORESCHI (2013) believes each fungal group requires an ideal condition to develop; thus, wood used in a variety of environments is exposed to attacks by different fungal species. In other words, the incidence of one or more fungal types in wood is closely related to conditions the wood is subjected to.

In the light of SHIROUZU et al. (2016), fungi are the main lignocellulosic-material decomposers among xylophagous organisms - phylum Basidiomycota is the most relevant one of them. These organisms are very efficient in decomposing wood due to their enzymatic ability to degrade molecules (SILVA, 2014). However, wood can be damaged in different ways; the attacked material can be only stained, or fully decomposed, by fungi (KOLLMANN et al., 1968; ROCHA, 2001).

As maintained by ZIGLIO (2015), two groups of fungi - i.e., staining and rotting — are associated with wood, and they just differ from each other in the macroscopic aspect observed in attacked wood. BLANCHETTE (2000) reported these organisms are classified based on the strategy they adopt to decompose wood constituents.

Staining fungi do not degrade cell wall components; thus, there is virtually no wood mass or mechanical property loss (MORESCHI, 2013). The action of these fungi only affects wood aesthetics due to discolorations or stains (Fig. 1A), which may be superficial or deep; however, they significantly reduce the quality and the commercial value of wood (BLANCHETTE, 2000; COELHO et al., 2007; BRITO, 2014). In other words, staining fungi have little ability to deteriorate wood constituents (SILVA et al., 2014). Ophiostoma (Fig. 1B) and Grosmannia are the genera representing this group (LUNDELL et al., 2014).

Another group of fungi is capable of causing soft rot. This group is featured by the ability to degrade polysaccharides often found in the outer sapwood layers in a relatively slow and superficial way; it is often resistant to wood preservatives. Wood undergoing advanced deterioration stages caused by these fungi becomes soft when it gets wet, it presents cracks due to shrinkage when it gets dry, and it gets powdery when it is rubbed (Fig. 2) (PORTO, 2010). Trichoderma, Phialophora, Paecilomyces, Aspergillus and Xylaria are the genera comprising the main fungal species belonging to this group (LUNDELL et al., 2014).

Brown rot is caused by fungi that often have high deterioration ability (SILVA, 2014). These fungi prefer cellulose and hemicellulose, and they do not affect lignin (KEREM et al.,
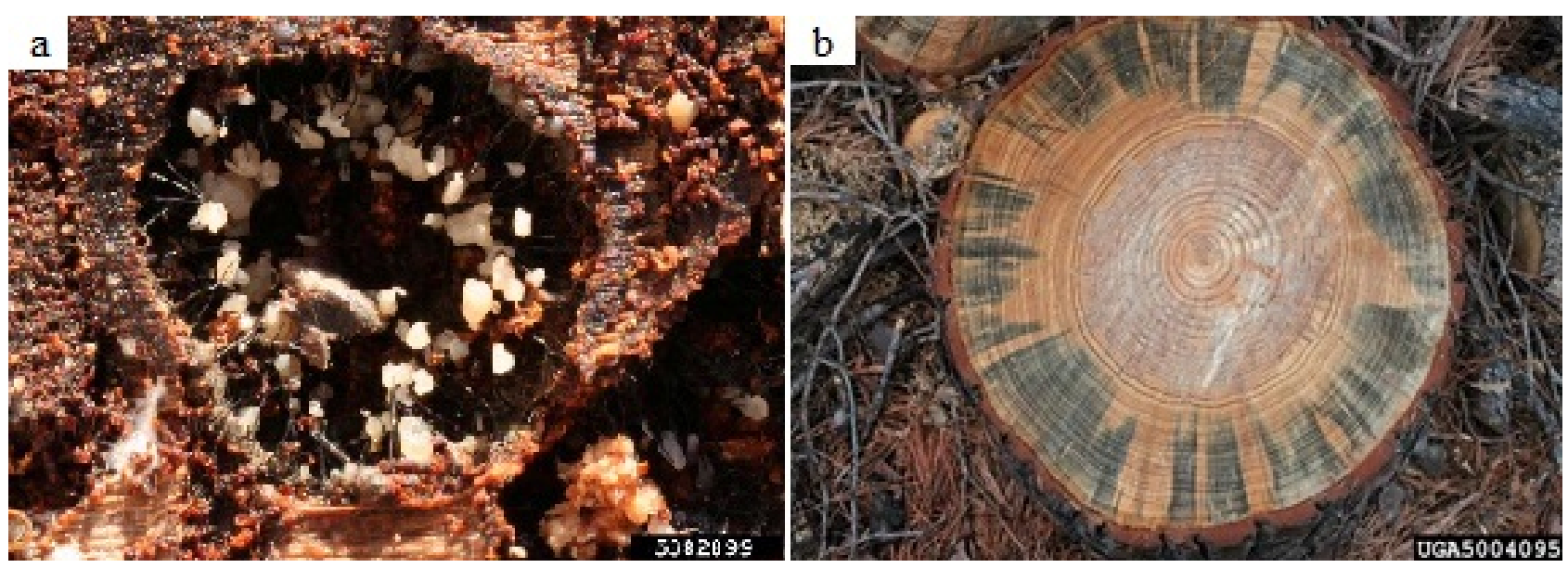

Source: KUNCA (2009); BILLING (2006).

Figure 1. (A) Appearance of wood attacked by staining fungi; (B) staining fungus species Ophiostoma piceae (Munch) Syd. \& P. Syd. 

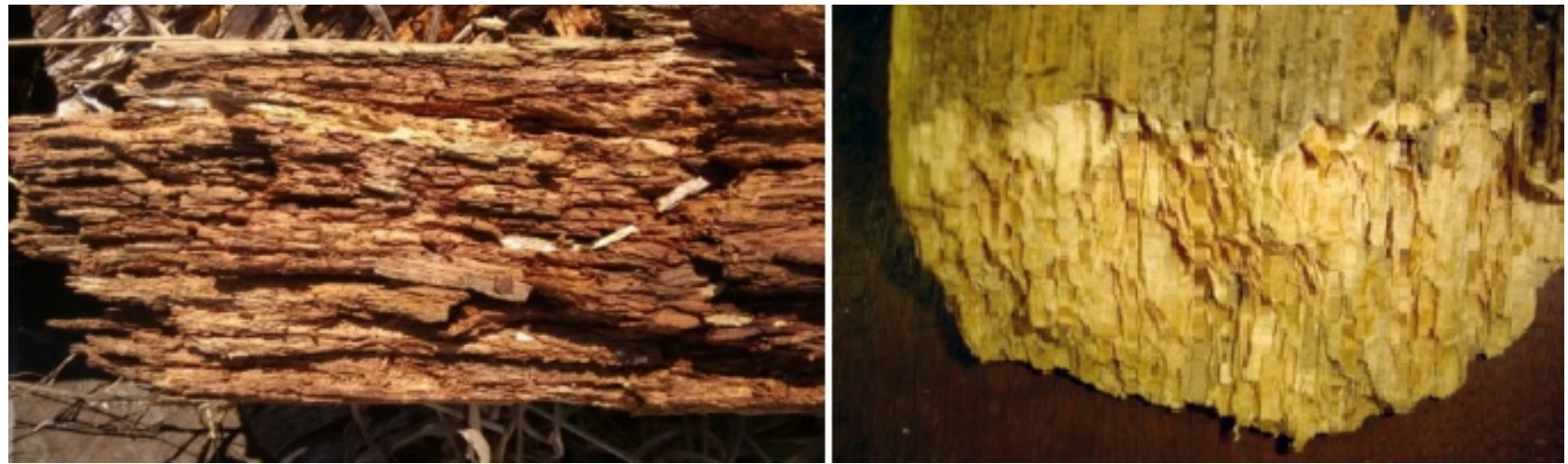

Source: CARVALHO et al. (2018).

Figure 2. Wood attacked by soft-rot fungi, at advanced deterioration stages.

1999; RILEY et al., 2014). Wood attacked by these fungi becomes dry, powdery, as well as presents dark brown color and acquires burnt and cracked appearance (Fig. 3A) (EATON; HALE, 1993; LUNDELL et al., 2014).

Wood attacked by brown-rot fungi presents significant resistance loss even at early decay stages (MARTÍNEZ et al., 2005). The aforementioned author stated that basidiomycetes are the only causative agents of brown rot; among them, one finds the following species: Coniophora puteana (Schumach.: Fr.), Gloeophyllum trabeum (Pers.) Murrill. (Fig. 3B), Laetiporus sulphureus (Bull.) Murrill., Piptoporus betulinus (Bull.) P.Karst., Postia placenta (Fr.) M.J. Larsen and Lombard. and Serpula lacrymans (Wulfen) P. Karst.

White-rot fungi are distributed in nature in milder climate regions (ESPOSITO et al., 1993). They are basidiomycetes capable of degrading all cell wall components, including lignin; they easily stick to the wood and cause discoloration in the attacked material (BLANCHETTE, 2000). Wood attacked by white-rot fungi loses mass, as well as its physical and mechanical resistance, due to collapse (Fig. 4A); however, such a loss is slower than that resulting from attacks by brown-rot fungi (GARCIA, 2006; MODES et al., 2012). In line with BLANCHETTE (2000), the ability of these fungi to metabolize large amounts of lignin in wood is unique among microorganisms.

On the report of MARTÍNEZ et al. (2005), the following species are some of the main representatives of white-rot fungi: Trametes versicolor (L.) Lloyd. (Fig. 4B), Polyporus squamosus (Huds.) Fr., Irpex lacteus (Fr.) Fr., Phanerochaete chrysosporium Burds., Heterobasidium annosum (Fr.) Bref., Ganoderma australe (Fr.) Pat., Phlebia tremellosa (Schrad.) Nakasone and Burds., Ceriporiopsis subvermispora (Pilát) Gilb. and Ryvarden., Pleurotus spp. and Phellinus pini (Brot.) Bondartsev and Singer.

As a rule, fungi-associated deterioration stages have different features. According to MENDES; ALVES (1988), the initial symptoms of an attack on wood differ from the ones seen at the most advanced stages; however, the longer the deterioration time, the easier the symptom identification process. Briefly, aspects such as smell, color, texture, as well as significant wood strength and density decrease, indicate fungal attack on wood (BRITO, 2014).

Color change is one of the first visible symptoms in wood attacked by fungi. It precedes wood chemical decomposition and is featured by the emergence of dark brown or purple stripes or bands. Dark brown spots or light stains can emerge on sawn wood depending on the fungal type (MENDES; ALVES, 1988).

Wood softening is another symptom of fungal attack; the attacked material presents brittle texture, which makes it impossible to remove whole pieces of it. It happens because fibers break whenever one attempts to remove a piece of wood and it makes the wood look like it had already been macerated (MENDES; ALVES, 1988). These fungi are capable of degrading cellulose and hemicellulose, although in a slow and superficial way; the surface of attacked wood gets softened and presents transverse cracks (GONZAGA, 2006). The attacked region in the wood presents loss of weight and mechanical resistance (MORESCHI, 2013).

Besides discoloration, weight loss is another feature associated with wood decay progress (MENDES; ALVES, 1988). The aforementioned authors believe it is necessary taking great care at the time to assess this symptom because the tree growth rate can affect wood color and specific density, which is often seen in fast-growing species, mainly in conifers. As stated by RITTER; MORRELL (1990), in some cases, the attacked material presents visual features of healthy wood depending on the fungal type; however, in most cases, wood density decreases from 1 to $5 \%$, and wood resistance can decrease by $60 \%$.

Change in smell is a feature of rotting fungi attack on wood, since they give it an unpleasant odor. The attacked wood starts presenting a characteristic smell, which is remarkably similar to that of airless and humid places. This smell is one of 

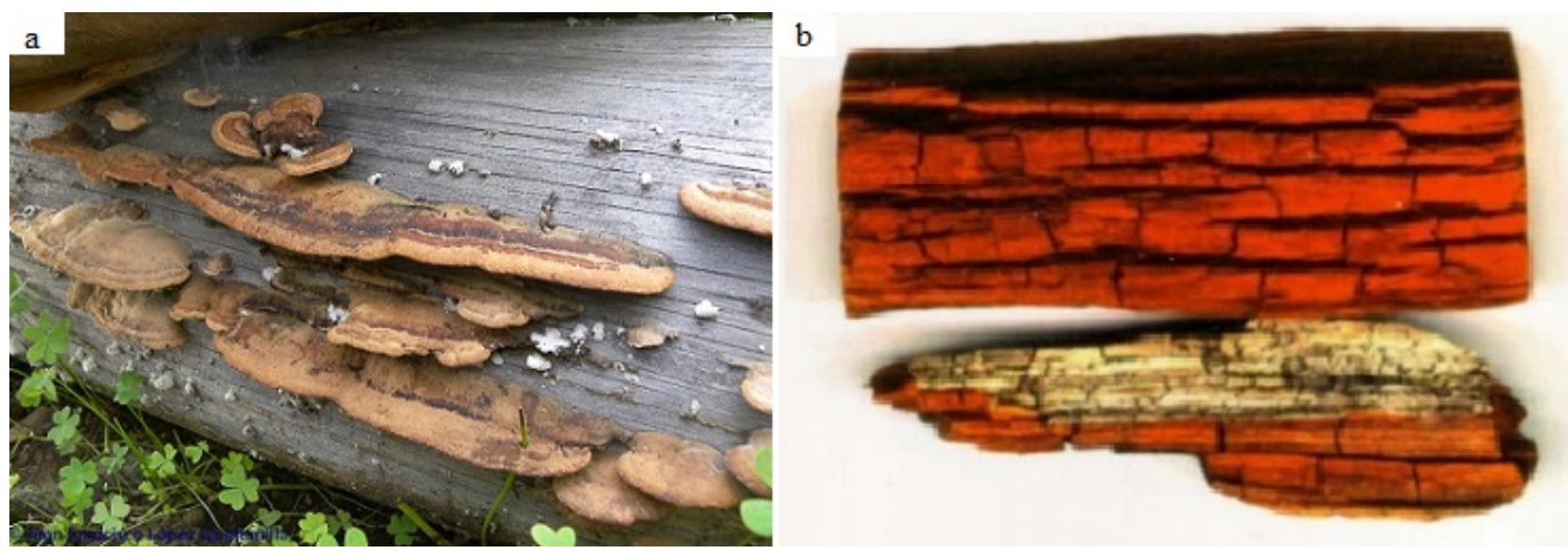

Source: MORESCHI (2013); QUINTANILHA (undated).

Figure 3. (A) Appearance of wood attacked by brown-rot fungi; (B) brown-rot fungal species Gloeophyllum trabeum.
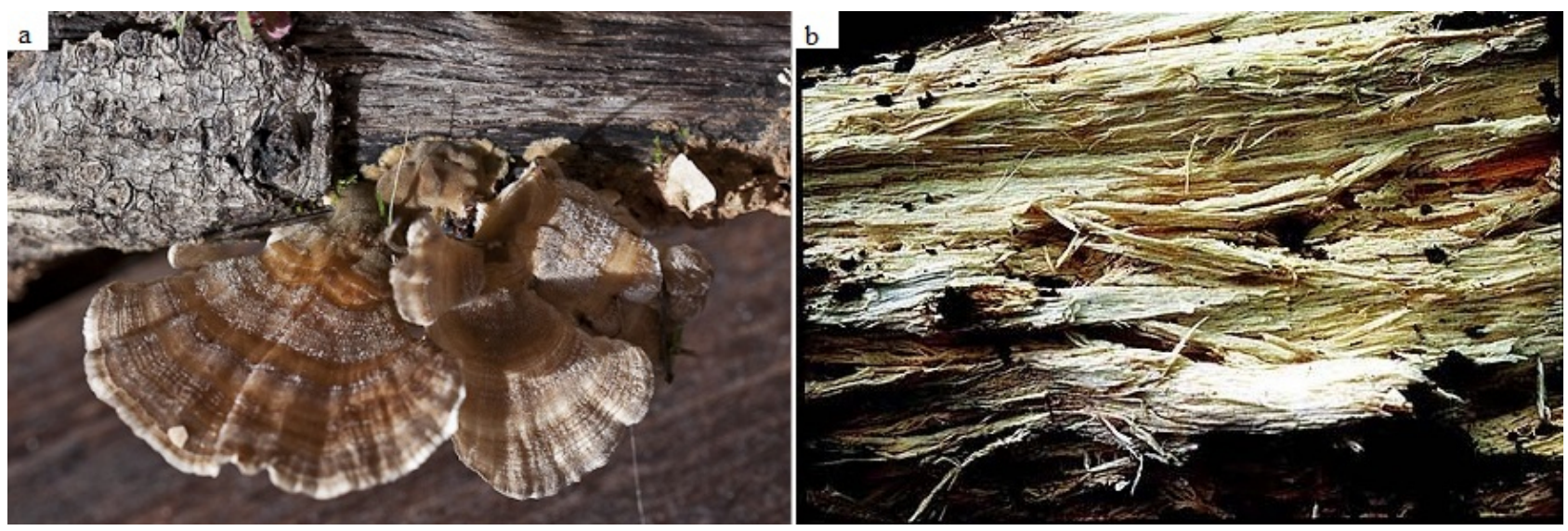

Source: SMITH (2020); VOLK (2010).

Figure 4. (A) Appearance of wood attacked by white-rot fungi; (B) white-rot fungal species Trametes versicolor.

the most significant symptoms used at the time to acknowledge (MENDES; ALVES, 1988).

Temperature, moisture, low levels of total toxic extracts in the wood and nutrients are the main factors enabling fungal attack on wood (OLIVEIRA et al., 1986). If temperature, oxygen, $\mathrm{pH}$ and moisture content in the wood present adequate fungal development conditions, all one needs to do to limit, and even prevent, the activity of these organisms is to manipulate any of these variables (MORESCHI, 2013).

The source of nutrients in wood can be eliminated through the application of preservative products (MENDES; ALVES, 1988). Preservative treatments increase wood resistance to xylophagous organisms due to the application of chemical preservatives (LELIS et al., 2001). This procedure consists in incorporating toxic chemicals to the fungi into cellular elements of the wood in order to avoid fungal and insect attacks (MENDES; ALVES, 1988). However, it is necessary taking some precautions, such as periodic preventive maintenance and/or corrective maintenance interventions, in order to assure satisfactory wood preservation procedures (LELIS et al., 2001).

Surface treatment is a way to protect wood from being attacked by these organisms. This method consists in applying the preservative product to the outermost part of the wood - by brushing, injecting or spraying it in order to prevent the attack on the newly exposed wood - or as a complementary procedure to be carried out a few years after the initial treatment. It is effective when the application is performed before biodeterioration starts and it presents limited effectiveness after internal biodeterioration is established. It is often used to treat fissures, splittings, cracks, delaminations and mechanical damages in wood regions presenting holes or cuts resulting from field work during construction, maintenance or rehabilitation processes (RITTER, 1990). 
Fumigants are used to mitigate established internal deterioration processes. This treatment uses specialized chemical preservatives, in their liquid or solid form, which are inserted in pre-drilled holes. Fumigants volatilize into toxic gases for a certain period and move through the wood to eliminate xylophagous organisms (RITTER, 1990). Some examples of fumigants comprise Phosphine (PH3), Methyl Bromide (CH3Br), Sulfuryl fluoride, Chloropicrin, Vapam and Vorlex (FLORIAM, 2009).

Humidity control is one of the simplest and most economic methods used to minimize wood deterioration risks. Wood exposed to reduced humidity levels can reach lower moisture content than the one necessary for the development of most fungi (RITTER, 1990). In line with the aforementioned author, it is a practical and effective maintenance technique used to increase the life span of the wood in service.

According to MORESCHI (2013), artificial wood drying is the most efficient fungal control method; however, it depends on the log yield rate of the company and is restricted to the use of appropriate dryers. However, drying can be naturally achieved, although this method often ends up keeping favorable conditions for fungal development for longer periods-of-time.

Oxygen is another factor that can be manipulated, because, although fungi can develop in wood at oxygen concentrations lower than $20 \%$, their development can be reduced, or even prevented, at very low, or in lack of, oxygen concentrations (MENDES; ALVES, 1988).

The most used practices to eliminate oxygen from wood surface comprise immersing the material in water, burying it to a depth where there is no soil aeration or keeping it under intermittent water spraying in order to isolate the wood from free oxygen through a water layer on the surface of the piece (MORESCHI, 2013).
The optimal $\mathrm{pH}$ range for fungal development lies between 4.5 and 5.5 , since the minimum $\mathrm{pH}$ is 2.0 and the maximum one is slightly higher than 7.0. The $\mathrm{pH}$ adjustment practice is only justified if the material to be protected is of high value due to costs with products used in this process (MORESCHI, 2013). MENDES; ALVES (1988) stated the ideal temperature for fungal development ranges from 25 to $30^{\circ} \mathrm{C}$, although fungal attacks can happen at temperatures ranging from 0 to $40^{\circ} \mathrm{C}$. However, the aforementioned authors claim that temperature control is unfeasible.

In light of the foregoing, control procedures aimed at preventing fungi from settling and developing in wood can be based on the manipulation of factors capable of favoring their development. As mentioned by FURTADO (2000), such control can be achieved through correct wood drying, storage under adequate temperature and humidity conditions, and through the application of preservative products.

Xylophagous fungi are seen as one of the main factors responsible for significant economic losses in the timber industry, since they affect physical, mechanical and aesthetic wood properties. The fact that one, or more, fungal species can be found in wood is explained by favorable conditions, since fungal agents can attack the wood in trees (before felling) and in several post-felling stages. It is highly necessary adopting control measures, both preventive and curative, aimed at wood preservation and conservation, to assure greater durability of the material in use and to avoid losses in the timber industry.

Studies about these fungal groups should be conducted to help improving the knowledge about the ecology and biology of the species to allow preventive measures to be taken. In addition, knowledge about the evaluation of fungal attacks allow appropriate curative measures to be taken based on the analysis of symptoms aimed at identifying the type of attacking organism and the attack stage.

ACKNOWLEDGMENTS: Not applicable.

FUNDING: This study was financed in part by the Coordenação de Aperfeiçoamento de Pessoal de Nível

Superior (CAPES) - Finance Code 001.

CONFLICTS OF INTEREST: All authors declare that they have no conflict of interest.

ETHICAL APPROVAL: Not applicable.

AVAILABILITY OF DATA AND MATERIAL: Data sharing not applicable to this article as no datasets were generated or analyzed during the current study.

AUTHORS' CONTRIBUTIONS: The article was conceived together. The writing -revision and editing: Mariano, L.G. That is, the first author was in charge of carrying out the bibliographic research and writing the first version of the manuscript. The other authors carried out a critical review of the text, suggesting changes in content and form. 
ALMEIDA, A.A. Biodegradação de produtos à base da madeira de cedro australiano (Toona ciliata M. Roem. var. australis). 2010. 102f. Dissertation (Master in Science and Technology of Wood) - Universidade Federal de Lavras, Lavras, 2010.

BILLINGS, R.F. Serviço Florestal do Texas A@M. Budwood.org. Texas, 2006. Available from: https://www.invasive.org/browse/detail. cfm?imgnum=5004095. Access on: May 102020.

BLANCHETTE, R.A. A review of microbial deterioration found in archeological wood from different environments. International Biodeterioration and Biodegradation, Birmingham, v.46, n.3, p.189-204, 2000. https://doi.org/10.1016/ S0964-8305(00)00077-9

BRITO, L.D. Patologia em estruturas de madeira: metodologia de inspeção e técnicas de reabilitação. São Carlos. 2014. 502f. Thesis (PhD in Structural Engineering) - Escola de Engenharia de São Carlos. Universidade de São Paulo, São Paulo, Brasil, 2014. https://doi.org/10.1 1606/T.18.2014.tde-18122014-090958

CARVALHO, D.E.; BROCHINI, G.G.; ROCHA, M.P.; LOIOLA, P.L.; DIAS, P.C.; GUIMARÃES, P.P.; CASTRO, V.G. Agentes com capacidade limitada de degradação da lignina. In: CASTRO, V.G.; GUIMARÃES, P.P.; CARVALHO, D.E.; SOUZA, G.O.; BROCHINI, G.G.; AZAMBUJA, R.R.; ROSA, T.S.; ROCHA, M.P.; LOIOLA, P.L.; DIAS, P.C.; PEREIRA, K.T.O. Deterioração e preservação da madeira. Mossoró: Ed. UFERSA, 2018. p.41-54. Available from: https:// livraria.ufersa.edu.br/wp-content/uploads/sites/165/2019/02/ deterioracao-e-preservacao-da-madeira002.pdf. Access on: May 102020.

COELHO, N.S.; HANADA, R.E.; DE JESUS, M.A. Identificação de fungos xilófagos depositados na Coleção de Microrganismos de Interesse Agrossilvicultural do INPA. In: JORNADA DE INICIAÇÃO CIENTÍFICA, 16., Manaus, 2007. Manaus: PIBIC CNPq/FAPEAM/ INPA, 2007. p. 155-156. Available from: https://repositorio.inpa. gov.br/handle/1/2893. Access on: May 102020.

EATON, R.A.; HALE, M.D.C. Wood: Decay, pests and protection. Cambridge: Chapman \& Hall, 1993.

ESPOSITO, E.; INNOCENTINI-MEI, L.H.; FERRAZ, A.; CANHOS, V.P.; DURAN, N. Phenoloxidases and hidrolases from Pycnoporus sanguineus (EUC-2050 strain): applications. Journal of Biotechnology, v.29, n.3, p.219-228, 1993.

FLORIAM, A. Preservação de Madeiras. Brasília: Universidade de Brasília, 2009. (Apostila de Secagem e Preservação de Madeira).

FURTADO, E.L. Microrganismos manchadores da madeira. Série Técnica IPEF, v.13, n.33, p.91-96. 2000.

GARCIA, T.A. Purificação e caracterização das lacases de Pycnoporus sanguineus. 2006. 126f. Thesis (Doctorate in Molecular Biology) - Universidade de Brasília, Brasília, 2006.

GONZAGA, A.L. Madeira: uso e conservação. Brasília: IPHAN/ MONUMENTA, 2006.
KELLEY, S.S.; JELLISON, J.; GOODELL, B. Use of NIR and pyrolysisMBMS coupled with multivariate analysis for detecting the chemical changes associated with brown-rot biodegradation of spruce wood. FEMS Microbiology Letters, Oxford, v.209, n. 1, p.107-111, 2002. https://doi.org/10.1111/j.1574-6968.2002.tb $11117 . x$

KEREM, Z.; JENSEN, K.A.; HAMMEL, K.E. Biodegradative mechanism of the brown rot basidiomycete Gloeophyllum trabeum: evidence for an extracellular hydroquinone driven fenton reaction. Federation of European Biochemical Societies Letters, v.446, n.1, p.49-54. 1999. https://doi.org/10.1016/ s0014-5793(99)00180-5

KOLLMANN, F.F.P.; KUENZI, E.W.; STAMM, A.J. Principles of wood science and technology. Solid wood, v. 1. Berlin: Springer-Verlag, 1968.

KUNCA, A. Centro Nacional de Florestas. Bugwood.org. Eslováquia, 2009. Available from: https://www.insectimages.org/browse/ detail.cfm?imgnum=5382899. Access on: May 102020.

LELIS, A.T.; BRAZOLIN, S.; FERNANDES, J.L.G.; LOPEZ, G.A.C.; MONTEIRO, M.B.B.; ZENID, G. Biodeterioração de madeiras em edificações. São Paulo: Instituto de Pesquisas Tecnológicas, 2001.

LUNDELL, T.K. MÄKELÄ, M.R.; DE VRIES, R.P.; HILDEN, K.S. Genomics, lifestyles and future prospects of wood-decay and 8 litter decomposing basidiomycota. Advances in Botanical Research, v.70, p.329-370, 2014. https://doi.org/10.1016/ B978-0-12-397940-7.00011-2

MARTÍNEZ, A.T.; SERANZA, M.; RUIZ-DUEÑAS, F.J.; FERREIRA, P.; CAMARERO, S.; GUILLÉN, F.; MARTÍNEZ, M.J.; GUTIÉRREZ, A.; DEL RÍO, J.C. Biodegradation of lignocellulosics: microbial, chemical, and enzymatic aspects of the fungal attack of lignin. International Microbiology, v.8, n.3, p. 195-204, 2005.

MENDES, A.S.; ALVES, M.V.S. A degradação da madeira e sua preservação. Brasília: IBDF/LPF, 1988.

MODES, K.S.; LAZAROTTO, M.; BELTRAME, R.; VIVIAN, M.A.; SANTINI, E.J.; MUNIZ, M.F.B. Resistência natural das madeiras de sete espécies florestais ao fungo Pycnoporus sanguineus causador da podridão branca. Cerne, v. 18, n.3, p.407-411, 2012. https:// doi.org/10.1590/SO104-77602012000300007

MORESCHI, J.C. Biodegradação e preservação da madeira Biodegradação da madeira. v.1. 4. ed. Curitiba: Departamento de Engenharia e Tecnologia Florestal da Universidade Federal do Paraná, 2013.

OLIVEIRA, A.M.F.; LELIS, A.T.; LEPAGE, E.S.; LOPEZ, G.A.C.; OLIVEIRA, L.C.S.; CAÑEDO, M.D.; MILANO, S. Agentes destruidores da madeira. In: LEPAGE, E.S. (Coord.). Manual de preservação de madeiras. v.1. São Paulo: IPT, 1986. p.99-279.

POPESCU, C.M.; POPESCU, M.C.; VASILE, C. Structural changes in biodegraded lime wood. Carbohydrate Polymers, v.79, n.2, p.362372. 2010. https://doi.org/10.1016/j.carbpol.2009.08.015 
PORTO, A.L.G. Questões de preservação: a madeira como estudo de caso. 2010. 235f. Dissertation (Master in Civil Engineering) - Universidade Estadual de Campinas, Campinas, 2010.

QUINTANILHA, L.F.L. Banco de cogumelos - Gloeophyllum trabeum. Espanha, s/d. Available from: http://www.bancodesetas.es/ banco-de-setas/contenidos/641/gloeophyllum-trabeum. Access on: May 102020.

RILEY, R.; SALAMOV, A.A.; BROWN, D.W.; NAGY, L.G.; FLOUDAS, D.; HELD, B.W.; LEVASSEUR, A.; LOMBARD, V.; MORIN, E.; OTILLAR, R.; LINDQUIST, E.A.; SUN, H.; LABUTTI, K.M.; SCHMUTZ, J. JABBOUR, D.; LUO, H.; BAKER, S.E.; PISABARRO, A.G.; WALTON, J.D.; BLANCHETTE, R.A.; HENRISSAT, B.; MARTIN, F.; CULLEN, D.; HIBBETT, D.S.; GRIGORIEV, I.V. Extensive sampling of basidiomycete genomes demonstrates inadequacy of the whiterot/brown-rot paradigm for wood decay fungi. Proceedings of the National Academy of Sciences of the United States of America, v. 111 , n.27, p.9923-9928, 2014. https://doi.org/10.1073/ pnas. 1400592111

RITTER, M.A. Timber bridges: Design, construction, inspection, and maintenance. Washington, DC: Forest Service, United States Department of Agriculture, 1990.

RITTER, M.A.: MORRELL, J.J. Bridge inspection for decay and other deterioration. In: RITTER, M.A. Timber bridges: Design, construction, inspection, and maintenance. Washington, DC: Forest Service, United States Department of Agriculture, 1990. Chapter 13. p.1-67.

ROCHA, M.P. Biodegradação e preservação da madeira. 5. ed. Curitiba: Fundação de Pesquisas Florestais do Paraná, 2001. 94p. (Série Didática, 01/01).

SANTOS, Z.M. Avaliação da durabilidade natural da madeira de Eucalyptus grandis W. Hill: Maiden em ensaios de laboratório. 1992. 75f. Dissertation (Master in Forest Science) - Universidade Federal de Viçosa, Viçosa, 1992.
SHIROUZU, T.; UNO, K.; HOSAKA, K.; HOSOYA, T. Early-diverging wood-decaying fungi detected using three complementary sampling methods. Molecular Phylogenetics and Evolution, v.98, p. 11-20, 2016. https://doi.org/10.1016/j.ympev.2016.01.015

SILVA, B.N.S. Seleção de fungos apodrecedores de madeira e caracterização de basidiomicetos associados à podridão de árvores vivas. 2014. $91 \mathrm{f}$. Dissertation (Master in Agronomy / Phytopathology - Forest Pathology) - Universidade Federal de Lavras, Lavras, 2014.

SILVA, L.F.; PAES, J.B.; JUNIOR, W.C.J.; OLIVEIRA, J.T.S.; FURTADO, E.L.; ALVES, F.R. Deterioração da madeira de Eucalyptus spp. por fungos xilófagos. Cerne, v.20, n.3, p.393-400, 2014. https:// doi.org/10.1590/01047760201420031462

SMITH, I. Morfologia de Trametes versicolor. Naturdata Biodiversidade Online. Portugal. Available from: https://naturdata. com/especie/Trametes-versicolor/1 1581/O/. Access on: May 102020.

TEIXEIRA, D.E.; COSTA, A.F.; SANTANA, M.A.E. Aglomerado de bagaço de cana-de-açúcar: resistência natural aos apodrecedores. Scientia Florestalis, Piracicaba, n.52, p.29-34. 1997.

VOLK, T. White Rot Aspen - Wood Rotters. Coleção de Fungos de Tom Volk. Coleção de Ensino de Planta. Universidade de Wisconsin. Madison. 2010. Available from: http://botit.botany.wisc.edu/ Resources/Toms\%2OFungi/Basidiomycota/Hymenomycetes/ General_--Wood_rotters/White_Rot_Aspen.jpg.html. Access on: May 102020.

ZIGLIO, A.C. Oleoresina de capsaicina como preservante natural de madeira de Pinus sp. contra a ação de fungos de podridão branca e de podridão mole. 2015. $101 \mathrm{f}$. Thesis (Doctorate in Materials Science and Engineering) - Instituto de Física de São Carlos, Escola de Engenharia de São Carlos, São Carlos, 2015. https://doi.org/10.11606/T.18.2015. tde-27082015-101533 